TORTURE, IDENTITY,

\title{
AND THE CORPOREALITY OF FEMALE SANCTITY: THE BODY AS LOCUS OF MEANING IN THE LEGEND \\ OF ST MARGARET OF ANTIOCH*
}

\author{
Andrew M. Beresford \\ University of Durham \\ a.m.beresford@durham.ac.uk
}

\section{Resumen}

La leyenda de Santa Margarita de Antioquía problematiza una serie de concepciones de la individualidad, sobre todo la relación entre el cuerpo y la identidad, al complicar constantemente la claridad dialéctica de la oposición entre el ser y el otro, entre lo interno y lo externo. Margarita, lacerada hasta un punto en que las operaciones internas de su cuerpo llegan a ser visibles, es tragada por un dragón, cuyo estómago revienta, expulsándola de su interior, cuando ésta se santigua. De esta manera llega a ser una figura compleja y ambivalente, una fuente de abyección más que objetificación escópica para Olibrio, el inquisidor pagano, y un modelo de resistencia heroica para una audiencia cristiana partidaria. En esta discusión, que se centra en la versión previamente inédita de su leyenda preservada en el Gran flos sanctorum castellano, se presta atención sobre todo a cuestiones de significado ontológico, la tal llamada tesis de la 'pornografía pía' y la apropiación del cuerpo femenino como lugar simbólico de significación.

\section{Palabras clave}

Hagiografía, Santa Margarita de Antioquía, tortura, identidad, corporalidad.

\begin{abstract}
The legend of St Margaret of Antioch problematizes a range of conceptions of selfhood, particularly the relationship between the body and identity, by constantly blurring the dialectical clarity of the opposition between self and other, between internal and external. Margaret, who is lacerated to the point where the

* This article was completed under the auspices of the research project "La literatura hagiográfica catalana entre el manuscrito y la imprenta" (FFI2OI3-43927-P), awarded by the Ministerio de Economía y Competividad.
\end{abstract}


inner workings of her body become visible, is swallowed by a dragon, but subsequently bursts outwards through its stomach by making the sign of the cross. She in this way becomes a complex and ambivalent figure, a source of abjection rather than scopic objectification for Olybrius, the pagan inquisitor, but a model of heroic resistance for a partisan Christian audience. In this discussion, which focuses on the previously unedited version of her legend in the Castilian Gran flos sanctorm, particular attention is paid to questions of ontological significance, the so-called 'pious pornography' thesis, and the appropriation of the female body as a symbolic locus of meaning.

\section{Keywords}

Hagiography, St Margaret of Antioch, torture, identity, corporeality.

As Elizabeth Grosz (1990, pp. 8I-82) has convincingly demonstrated, the human body has been conceptualized in the works of a range of contemporary theorists — from Lyotard to Irigaray, Deleuze, Derrida, and Foucault — as a fundamentally historical and political object over which relations of power and resistance have been played out. As the central element in the individual's psychic formation, the irreducible materiality of the body can be regarded not solely as a condition of subjectivity, but as a source of cultural and ideological inscription that allows the subject to become coded, made meaningful, and rendered representable as it becomes interlocked into a range of signifying systems. This process, which challenges the traditionally deleterious position of the body as the brute and inferior half of Cartesian dualism, functions as a force of ontological stabilization, allowing the subject to become part of the orderly and regulated production of discourses and stabilized meanings. Yet it also, as Grosz (1990, pp. 86-93) recognizes, provides for the possibility of a disruption and breakdown in the symbolic registration, both of the subject and of the discourses into which it is interlocked. If, for instance, our perception of the dialectical integrity of the distinction between interior/exterior - between the hidden inner workings of the body and its sanitized and socially acceptable surface- is challenged or partially inverted through the operation of procedures capable of eliciting moods of abjection, we can become drawn inexorably to a place where theoretical discourses begin to break down and the production of stabilized meaning becomes difficult or impossible to sustain. 'The subject, unable

\footnotetext{
' For abjection, see Kristeva (1982), Smith, Lechte, Oliver, and McAfee.
} 
to engage in a natural and instinctive process of specular identification -overlaying the self seamlessly onto the other through acts of mimetic identificationcan find it difficult to position itself within the symbolic order or recognize the object as fully human. ${ }^{2}$ The process reaches its most obvious and horrific extreme in relation to questions of (forced) ontological amalgamation and hybridity, as our customary desire to impose system and order is challenged when the clarity of the once clearly demarcated borderline between self/other, subject/object, or internal/external becomes blurred or is rendered wholly indistinct. ${ }^{3}$

Grosz's reading of the relationship between corporeality and subjectivity has implications for an enhanced appreciation of some of the commonplaces of medieval hagiography, and in particular, the extent to which the tortures and mutilations inflicted on the bodies of the martyrs challenge our perceptions of ontology and identity, making it difficult at times to advance an informed understanding of where the borders of selfhood begin and end. It reflects, in particular, on the forcible separation of object from subject, the integrity of the dialectical distinction between internal and external, and how the question of corporeal integrity is regarded both by the self and by others. It also requires a consideration of the significance of the epidermis, which, in ordinary circumstances functions as a type of impermeable layer, mediating contact between the perceived essence or inner core of the subject and the corruption of the outside world. ${ }^{4}$ These issues are manifest in representations of corporeal fragmentation and the ways in which the fragile insecurity of the body can be challenged as a locus of meaning by acts such flaying, gorging, and dismemberment, all of which are capable of effecting an artificial distinction between subject and object. ${ }^{5}$ Amongst the most familiar examples are Agatha, whose breasts are severed, Lucy, whose eyes are gouged out, and Christina, who gathers her severed tongue in her hands and throws it in the face of her executioner. ${ }^{6}$ In other instances, however, the process of fragmentation is by no means as clear cut, and notable in this respect are saints such as

2 Mimetic identification has been cogently addressed by Camille, who shows how late medieval Christians approached Christ as human and vulnerable rather than divine and ineffable by focusing on questions of corporeality and the correspondence between his body and their own.

${ }^{3}$ See amongst others, Binski, Merback, and Mills, and for reactions of disgust more generally, Miller.

${ }^{4}$ Skin studies have grown exponentially in recent years, and for valuable insights, see Anzieu, Benthien, Connor, Mills (pp. 59-82), and Walter.

${ }^{5}$ For the theoretical background to the subject/object division, see Kristeva (20I2).

${ }^{6}$ For Agatha and Lucy, see Beresford (2010), and for Christina, whose legend is unedited, BNM 78 o fols. $256^{\text {rb }}-258^{\text {ra }}$. 
Adrian and Vincent, whose status is problematized to a more significant degree as their entrails are exposed to the elements and the inner workings of their bodies become visible. ${ }^{7}$ In each instance, the epidermis that once fully contained the body's liquid interior is no longer able to perform its essential anatomical function and maintain the integrity of the distinction between internal/external and self/other. Accordingly, the saints are reduced to the status of an ongoing ontological ambiguity; figures trapped in an in-between state that disturbs all that we conventionally regard as constituting identity, system, and order (see Kristeva, 1982, p. 4).

The complexity of the relationship between corporeality and subjectivity is taken to its most natural extreme, however, in the legend of Margaret of Antioch, who is presented uniquely in the medieval hagiographic canon as a saintly container whose body functions as an overarching structuring principle or leitmotif, notably when its interior spills out before the eyes of her executioner and when she shortly afterwards bursts out of the belly of a dragon. These actions, which, as we shall see, can be related conceptually to a number of other aspects of her legend, elicit feelings of nausea and disgust that are so powerful, and so unmistakably abject in nature, that even those who once subjected her body to their sexualizing and fetishizing gaze can no longer bear to do so. They also challenge traditional conceptions of the borders and limitations of corporeality and subjectivity, making it difficult at times not only to determine the distinction between the body and its broader physical environment, but the extent to which identity itself becomes fluid and malleable, producing a range of unstable, and, in certain instances, paradoxical or contradictory patterns of literal and symbolic correspondence. The legend, accordingly, undermines confidence in conventional taxonomies, offering a lucid illustration both of the relevance and applicability of Grosz's theories, and of the ways in which the visceral savagery of the medieval hagiographic canon can expand and extend their functional remit.

Margaret's status as a corporeal container is signalled in the most authoritative version of her legend - a multi-volume compendium known as Compilation A or the Gran flos sanctorum - in the prefatory discussion of etymology, which presents the pearl (a play on the etymology of her name) in terms of the security of the body as a bounded system and as an effective defence against effusions of

${ }^{7}$ For Adrian, see BNM 12689 fols. $73^{\text {rb }}-75^{\text {va }}$ and Escorial h-II-I8 fols. $130^{\text {ra }}-132^{\text {va }}$, and for Vincent, BNM I2688 fols. $22 \mathrm{I}^{\mathrm{vb}}-224^{\mathrm{ra}}$ and Escorial h-III-22 fols. $\mathrm{I} 2 \mathrm{O}^{\mathrm{rb}}-\mathrm{I} 24^{\mathrm{ra}}$. 
blood from within. ${ }^{8}$ It is also counterpointed by the opening stages of the narrative proper, which interrogate the borders of selfhood by formulating an arresting distinction between the saint's self-image (a fifteen-year-old Christian shepherdess who idyllically tends her flocks in the meadows), and those that are imposed upon her by Olybrius, the Roman prefect. Through the power of the scopic drive, which represents the voyeuristic pleasure in seeing, Olybrius projects a pair of potential identities upon her, envisioning her, if noble, as his wife, or if baseborn, as his concubine. The common denominator is a prurient and intrusive process of sexualization that allows for the expression of a minor variation in the identity of the object, but not for the expression of agency. In fact, in his scopic imagination Olybrius re-projects Margaret's body not solely as a possession to be enjoyed but as an object already penetrated: a pliant and noble wife attentive to his sexual desires, or a pliant peasant, whose body is his to possesses on demand or reject when his predatory masculine appetites have been sated.'

The encounter between Margaret and Olybrius can be appraised from a number of theoretical perspectives, but of particular relevance is the work of Laura Mulvey, which focuses on the determining power of the male gaze and the perpetuation of the traditionally binary distinction between active/male and passive/female roles. ${ }^{10}$ By projecting his fantasies outwards and re-reading the shepherdess as an object of libidinal enjoyment, or as Mulvey puts it, the "leit-motif of erotic spectacle" (1975, p. II), Olybrius codes her appearance for visual and erotic impact. In this way she passively connotes the quality of "to-be-looked-atness" (1975, p. II). Yet by rejecting Olybrius's advances and reasserting the right to self-determination, Margaret returns the sexualizing gaze to its point of origin with such force that the scopic projection of identity comes crashing down and he begins to feel threatened by the unreality of his aspiration. The fantasy image of sexual union serves in this respect not to satisfy his libido, but to catalyse a

${ }^{8}$ An edition of BNM 780 (fols. $245^{\mathrm{ra}}-247^{\mathrm{rb}}$ ) is given as an appendix. Vocalic and consonantal functions of $i / j$ and $u / v$ have been regularized, while initial double consonants have been replaced by singular forms; $\xi$ has been retained before $a, o$, and $u$, but is otherwise transcribed as $c$. Accents, punctuation, and word division follow modern practice, with the exception of medieval compounds, which are given as they appear. For Compilation B, see Baños Vallejo and Uría Maqua (pp. 203-206), and for an index of filiations, Beresford (2010, pp. 243-250).

9 As Julie E. Fromer writes: "Margaret's position in the text is determined by the perceptions of those around her; when she is seen as loved by God, she is allowed to tend sheep in peace, but when Olibrius arrives and perceives her as a sexual commodity, her body is transferred to his control" (p. 94).

Io See Mulvey (1975) and (1989), and for an extrapolation of her ideas, Chaudhuri (pp. 3I-44). 
process of mutual (mis)recognition and concomitant disavowal that establishes and sharpens the polarity between the two characters. The most tangible result is the production of a paradoxical and asymmetrically symbiotic situation in which, as Judith Butler (p. 37) notes, the self strives to recognize and constitute itself by annihilating its other specifically in order to affirm the boundaries of its own existence. The process, for Olybrius, constitutes an assertion of male power and the penetrative potential of the phallus and its surrogates. For Margaret, on the other hand, the emphasis falls on the body/soul relationship and the ability of the self to rise above its corporeal limitations and reject the unwarranted imposition of a stereotype of passive sexual compliance. In so doing, she repudiates procedures for the external authoring of identity, whilst exercising the right to project an image of her authentic self as a bounded entity or sealed container whose borders cannot be compromised by the phallus.

Margaret's rejection produces the first of many ironies. The body that cannot be violated — the corporeal container remaining anatomically intact — is thrown into prison, where it is contained by bricks and mortar. The conflation of impressions of anatomical and architectural space, although in many ways a common hagiographic formula, functions throughout the legend as a structuring principle, mapping the construction of self-image onto a sequence of episodes that emphasize the interrelatedness of the human body to its broader physical and social environments. The common denominator in each instance is an emphasis on inadequacy and ineffectuality, with Olybrius unable to effect a transformation in Margaret's identity through the imposition of a range of strategies for coercive domination. This is attested partly by the way in which the shepherdess emerges unscathed from her period of incarceration - her unpossessable body visibly unweakened or turned against itself as a result of a primordial desire for denied food and comfort, as Elaine Scarry observes - but perhaps most tangibly in the subsequent altercation between the two main protagonists, which culminates in a threat to shatter Margaret's corporeal integrity: "Si non fizieres lo que te digo, faré despedaçar el tu cuerpo" (1l. 36-37). The ironies, of course, are manifold. Olybrius, unable to penetrate the saint's body with the phallus, is forced to do so, as Julie E. Fromer (pp. 95-96) recognizes, with weapons of torture and destruction. Yet in so doing, he functions unwittingly with the force of an exogenous agonist, becoming the agent of Margaret's desire to emulate Christ and become one with him in suffering as a result of the ontologically self-defining process of imitatio Christi.

The most significant implication, however, is structural, for by opting to have Margaret successively racked, whipped with rods, and lacerated, we are reminded 
once again of the prefatory discussion of etymology, as her bones become visible and blood gushes outwards in a torrent from her now shattered and broken body:

mandóla colgar en un tormento que era llamado eculeo, e açotar con vergas con mucha crueldat, e rasgar sus carnes con peynes de fierro, fasta que se le parescían los huesos. E corría la sangre de su cuerpo asý como de una fuente muy clara. (1l. 39-42)

The specificity of the tortures inflicted on the saint is not in itself important. As acts, they have only minimal symbolic or sequential significance, and could be rearranged or replaced by a range of others. The fundamental point, as far as a theoretical appreciation of the legend is concerned, is that they succeed in dissolving the dialectical integrity of the distinction between internal/external and self/other. Margaret, once a bounded entity marked by ontological integrity, begins to spill out over the borders of her former self, as parts of her body, particularly blood and flayed skin tissue, are forcibly integrated into their broader physical environment. The distinction between subject and object is in this way rendered ambiguous, imprecise, uncertain. As onlookers, the audience instinctively experiences moods of empathy and compassion, but faced by a breach in the once impermeable boundary of the epidermis, it also experiences nausea and disgust. ${ }^{\text {II }}$ As a result of a process of mimetic identification and the recognition of an essential form of homeomorphic correspondence, Margaret's body is in some ways conflated with that of the audience. Accordingly, her wounds become a mechanism for ontological superimposition and for the development of affective, intersubjective bonds. Yet the impression of similarity is marked also by difference, for while she suffers excruciating pain with fortitude and stylized grace, characterizing herself in so doing as a figure of saintly impassibility, she at the same time becomes superlative in our eyes, compelling the audience to recognize that her perfection cannot be emulated in anything other than partial and symbolic terms. She is in this way rendered ambiguous: a distressingly unattainable source of inspiration, marked as similar, but also as liminal and uncanny.

${ }^{\text {II }}$ As Mitchell B. Merback writes: "Images of wounds may be the paradigmatic generators of horror, and perhaps also disgust, because of the way they locate perception at the pulsing boundaries of the body. Once a wound appears before our eyes, it is as if a fault line has opened up across the body's topography, one that threatens to tear open the ever wider expanses of the body's hidden interior" (p. II3).

${ }^{12}$ See Mills (p. 82), and for a broader discussion of pain, Dendle. 
On witnessing Margaret's once desirable exterior violated by instruments of torture and mutilation - the protective covering of flesh partially stripped away from the workings of its once forbidden interior - even the pagan onlookers experience moods of empathy and mimetic identification. ${ }^{\mathrm{I} 3}$ Yet trapped by their own belief-system, they urge a course of action which is inappropriate, encouraging the saint to submit to the authority of pagan icons. The problem, as Paul Binski remarks in his landmark analysis of death, is that Christianity operates according to the application of a fundamental structural paradox. The life that the pagans zealously encourage Margaret to maintain constitutes death in her eyes; not the physical death of the body, which is merely a transformative obstacle to be negotiated on the path to celestial fixity, but to the everlasting life of the soul. Crucial to note in this respect is the latent inculcation of ideology, for by characterizing Margaret not as living but as one of the dead-to-be, the legend marks the passage from this world to the next as a transition from pain and ontological uncertainty to the salvific assurance of the afterlife. The corollary is that while in heaven the saved enjoy a life more real than that of Earth, the living are encouraged to see themselves not as alive, but as figures trapped in a qualitatively inferior realm of uncertainty in which the intercession of departed souls becomes essential for salvation. It follows, therefore, that the dead are not dead, or indeed banished from existence, but merely reinterpreted, as Binski suggests, in the context of a radically reconfigured relationship to the living (p. I2). Death is not in this sense an event that signals closure, but a rite of passage in which the emphasis falls on progression and teleological development.

Margaret emphasizes the conceptually meaningless nature of the pagans' words by fashioning a twofold inversion, contrasting "cuerpo" first with "coraçón", the source and foundation of her affective bond with Christ, and then with "alma" (11. 48-49), which, in contrast to the exterior shell, remains as ineffable as it is indestructible. Her response reflects in part on the inversion of the life/death antithesis, but impacts most tellingly on the broader structural development of the internal/external dichotomy. The implicit suggestion is that the destruction of the physical exterior, the corteza, is a necessary prerequisite for the release of the

I3 "Margarita, grand conpasión avemos de ti, porque veemos despedaçar el tu cuerpo con tan grand crueldat, e que pierdes la tu fermosura por la tu descrencia e porfía" (1l. 43-44). Fromer advances a different reading, arguing that: "Margaret's beauty was first mediated by Olibrius' lecherous gaze; now it is conveyed to us by the spectators who watch it being destroyed. In both cases, our position as readers is removed from the actual scene, and instead of watching the torture scene ourselves, we watch the watchers and form images based on their reactions" (p. 98). 
soul, the meollo, and the achievement of salvific certainty. It is a rite of sanctification that focuses attention on the flesh/spirit boundary and the consequences of separating the two. The body, which is associated purely with death and uncertainty, is destroyed in order to liberate the soul, which aspires to celestial fixity. It is in this sense nothing more than a fleshly prison, which, when destroyed, allows the saint to strengthen her aspirational identity and ascend to the freedom of paradise. Its significance is not only paradoxical in this respect, but functionally symbiotic, for without it she would be denied the opportunity to display the exemplary resilience necessary for recognition as a martyr. ${ }^{\mathrm{I}}$

As we expect, Margaret's reasoning defeats the pagans, who, despite experiencing feelings of abjection, continue to remain loyal to Roman authority and the public display of coercive power. She is as a result thrown into prison for a second time; her soul, only barely contained within her body, now immured by penal confinement. With the distinction between architectural and anatomical space dissolving once again into uncertainty, the legend becomes cyclical in nature and is marked to a certain extent by a lack of narrative progression. Yet in other respects, there are developments, for while Olybrius initially constructed Margaret as an object of sexual desire, witnessing her tending her flocks in the meadows, and, like a predatory wolf, yearning to devour her, the sexualized "moça fermosa" (1. 17) of his imagination has been transformed by torture into a sight that he can no longer bear to behold. ${ }^{\text {I5 }}$ This produces a further irony, for while the process of ocular reception once effected a transformation in her ontological status, with an innocent shepherdess evolving into the fictitious but sexually pliant wife/concubine dualism, his vision can only now alight on the breach in her body and the effusion of blood from within. The result is that instead of engendering desire, she becomes a trigger for disgust and abjection, and so he has little option but to cover his eyes: "E el adelantado cubría su cara con $e$ manto, non pudiendo ver tanta sangre como salía della” (1l. 49-5I).

The vision that formulated Margaret as a figure of fantasy is unable to countenance the reality that she has become: a mangled and lacerated heap of flesh characterized by the extension beyond the surface of its once forbidden interior.

${ }^{14}$ Elaine M. Treharne offers a different interpretation: "The earthly vessel housing the soul is unimportant in all ways except in that it protects the soul (and the soul's purity, which in the Life of Margaret is synonymous with physical purity) and should be venerated for that reason. If an assault on the spirit must involve physical mutilation leading to the body's ultimate destruction and death, then, it is stressed, at least it is a temporary death and eternal life will be the reward" (p. 233). See also McFadden (p. 48I).

${ }^{15}$ For Margaret as the paschal lamb, see Hill (p. 237). 
Although Olybrius persists in his attempt to assert the authority of the phallus, his experience of Margaret as an object of abjection is now pronounced, and, by covering his eyes, he enters into a process of symbolic denial, disavowing the agency of his scopic drive in producing the mangled physical wreck that she has become. The implication is that he has for the first time understood her as a subject rather than an object, envisioning her not as a mere chattel or sexually objectified other, but as an entity with a physical form that closely corresponds to his own. The process of abjection is in this sense a recognition of similarity and correspondence, and a rejection not merely of a shattered and fragmented self, but of the corpse that lingers at the periphery of perception, forever threatening to contaminate and eventually become the observer. ${ }^{16}$ The identities of saint and executioner are in this respect more fluid and polymorphous than they initially appear, for although the opposition between pagan and Christian is diametrical in nature, the recognition of Olybrius's own post-mortem other in the figure of Margaret produces a sense of ontological doubling and partial superimposition that succeeds in obscuring the apparent fixity of the borders of identity. The narrative accords in this respect with Robert Mills' assertion that "saints functioned in the Middle Ages as heterogeneous figures, incorporating a body of contradictory discourses in which lines between object-hood and subject-hood were often blurred" (p. I22).

The experience of abjection offers an invaluable hermeneutic for a consideration of the critical discourses that have in recent years related piety to pornography, adducing that the destruction of the female body can be interpreted as a form of displaced rape that inscribes hagiographic narratives as products of misogyny and the ideological imposition of a range of latent patriarchal values. The thesis, promoted by most forcefully by Kathryn Gravdal and reiterated to varying degrees in the work of Simon Gaunt and Karen A. Winstead, posits that scenes of torture and mutilation are aimed at a predominantly male audience, which is afforded a conveniently licit space in which to revel in descriptions of female subservience and corporeal destruction. They in this way both confirm and promote the existence of an implied hierarchy of gendered perception. The suffering female body, on the other hand, becomes a locus not for empathy and

${ }^{16}$ As Kristeva writes: "If dung signifies the other side of the border, the place where I am not and which permits me to be, the corpse, the most sickening of wastes, is a border that has encroached upon everything. It is no longer I who expel, 'I' is expelled" (I982, pp. 3-4). The abject functions in this respect as a reminder that the individual will cease to be, of "that elsewhere that I imagine beyond the present" (p. 4). Pointedly, Olybrius refers elsewhere to Christ as "[e]l crucificado" (1. 25), which suggests a comparable form of aesthetic repudiation. 
the formulation and development of intersubjective bonds, but for fetishistic enjoyment and sexual gratification; a fantasy of coercive objectification produced by a fundamentally male supremacist ideology. Female members of the audience, in contrast, if included at all, are placed in a rather more deleterious position: compelled to internalize negative indoctrinatory perceptions about their bodies and identities, and to regard themselves ultimately as the inferior half of a gendered dichotomy. ${ }^{\text {I7 }}$

The thesis, which has been dismissed as "reductive and simplistic" by Katherine J. Lewis (p. 70), who writes specifically on Margaret, and, more comprehensively by Robert Mills (pp. Io6-44), whose carefully nuanced analysis describes a process of polymorphous cross-identification that undermines confidence in conventionally gendered and heterosexual taxonomies, is undermined by the fact that in place of voyeuristic pleasure and masochistic depravity, even the pagans who scrutinize Margaret's agony experience revulsion, horror, and disgust. ${ }^{\mathrm{I}} \mathrm{T}$ Their reaction, which is ultimately one of abjection, destabilizes the impression of worldly authority afforded initially by Olybrius, and even if a Christian audience is able to recognize the symbolic and paradoxical value of torture as a mechanism for achieving salvation, his reaction in turning away, physically sickened by the sight before his eyes, exerts a powerful influence on the external audience, guiding and conditioning our reaction in comparably mimetic terms. Although we cannot, of course, discount the possibility that some members of the audience could have entered into a purely partial form of engagement, closing off their aesthetic sensitivities to descriptions of nausea and disgust in order to affix their attentions on the voyeuristic fetishization of the female body, the emphasis of the legend clearly lies elsewhere. In fact, as a celebration of triumphal resistance, it is formulated not as an invitation for men to engage in a form of collectivized symbolic rape, but for believers (male and female alike) to laud the evolution of a passive victim into an active agent, and to read Margaret's opened body as a way of counterpointing the humiliation and ineffectuality of phallocentric pagan authority.

${ }^{17}$ Susan Mary W. Withycombe writes: “Olibrius desires Margaret's body the instant he sees her; her refusal of his offer of marriage — an offer he cannot imagine any woman refusing, considering his wealth and rank- arouses his jealous anger, and his frustrated sexual desire turns to sadism. Hence the lurid, almost pornographic aspects of the torture scenes" (p. 176).

${ }^{18}$ As Mills argues, if hagiography functions as pornography, it could not have done so for the majority of female readers, unless of course we are prepared to consider the possibility of large scale queer reception (p. I22, p. 138). More fundamentally, if torture scenes function as acts of figurative rape, critics have not yet been able to explain why or to what end they were constructed with that purpose in mind. 
This does not mean, of course, as Mills affirms, that we should precipitously adduce that "virgin martyr depiction is devoid of erotic significance, or that martyrdom iconography precludes identification with sadistic aggression" (p. I28). It does succeed, however, as Lewis (p. 78) observes, in effecting a conceptual transformation in the value of the torments inflicted on Margaret's body, for as she willingly subjects herself to acts of torture and mutilation, she appropriates and redirects their meaning by transforming them into a self-representational act. Her saintly agency leads in this respect to an appreciation of a fundamental ideological irony, for as self-will is in itself a manifestation of a latent desire for Christo-mimetic identification, it becomes possible to argue, as Fromer suggests, not only that God is "aware of the physical nature and earthly focus of those who witness Margaret's torture", but that he effectively uses the same publicly displayed body in order to make his power visible to the witnesses, and in this way invert "the original intentions of the tyrant who initially displayed and tortured that body" (p. IOI).

It becomes extremely difficult, in view of this, to accept the view, articulated most forcefully in relation to Margaret by Elizabeth Robertson, that torture provides an antidote to the inherent sexual temptation that characterizes the depiction of female saints in the Middle Ages. Indeed, writing more broadly on the representation of female religious experience, Martha Easton goes as far as to describe the battle against temptation as something of a leitmotif, affirming that the beautiful young female saints are tortured and killed "not because of their Christianity per se, but rather because their beliefs keep them from succumbing to sexual temptation" (p. 5I). While there can, of course, be no doubt that hagiographic subjectivity is corporeal in nature, and that salvation is often achieved through the body, there is no evidence to suggest that Margaret experiences sexual temptation or that its debilitating effects are expunged by acts of extreme physical endurance at the hands of Olybrius. On the contrary, the problem, as Fromer avers, is that Margaret's body, rather than being formulated as "the agential locus of sensory perception, is the physical object that is perceived by other characters" (p. 92). It becomes impossible, accordingly, to regard the sexualization of the saint as anything other than the product of external agency, and of the corporeality and lust that originate in Olybrius and are imposed upon her through the power of scopic objectification.

At a more fundamental level, as Juliana Dresvina (pp. 158-159) recognizes, Robertson's reading fails to distinguish between metonymy and metaphor, between identical and adjacent, and in so doing, it comes dangerously close to blurring the distinction between temptation and victimization, tainting the purity of 
the saint with the broad-brush sexualized misogyny of the Middle Ages. Even if, as Dresvina (p. 159) adds, Margaret becomes an involuntary trigger of Olybrius's lust, this does not in itself imply that she is sexually tempted or that the various versions of her legend are structured by a process of sexualized mirroring. In the Castilian text, in fact, Margaret does not fear that she will be tempted to lose her virginity; nor is her experience of the world and the devil presented, as Robertson suggests, as being "conditioned by her continual experience of the temptation of the flesh" (p. 272). Moreover, Robertson's attempt to impose a simplistic dichotomy in which male saints are able to transcend their corporeal limitations while the spirituality of their female equivalents remains rooted in them, is not only reductive, but impossible to sustain on the basis of literary or visual evidence. ${ }^{\text {I9 }}$ It also, rather more ominously, enshrines the implicit implications of the pious pornography thesis at the level of contemporary academic discourse, presenting the female subject not as empowered through impassibility and triumphal suffering, but as marked at the outset by an inherent weakness and inferiority that can be perceived both at the level of internal narrative dynamics, and in terms of reception, with an extradiegetic female audience reminded by her example of its essentially fallible and lustful nature. The fundamental problem with this reading, of course, is that as Fromer notes, it not only presupposes a struggle against female nature, but that the female subject herself is characterized by "a pre-existing desire for sexual union with a man" (p. 93).

In prison for a second time, Margaret's violated and opened body is mapped once again onto the broader relationship between architecture and anatomy, as she is immured by the bricks and mortar of her cell. Olybrius, who, as we have seen, is unable to penetrate her with the phallus, finds himself compelled to do so instead with weapons of torture and mutilation, which, by serving as phallic surrogates, compensate for the impotence with which he is now characterized. A dual process of projecting subject onto object serves to reinforce the strength not only of the symbiotic relationship between Margaret and Olybrius, but of the extent to which their identities have become functionally interlocked into procedures of ontological transformation and becoming. Motivated initially by the

19 As Jacqueline Murray writes: "recent studies of the body have tended to reinforce the medieval notion that women had specific, sexed, marked bodies whereas men had human bodies [...]. Thus, many scholars' well-intentioned and necessary desire to integrate women into the category of humanity has served to perpetuate the medieval tendency to naturalise and universalise bodies as 'flesh', 'the body' or 'the human body' and consequently to obscure the sexual specificity of embodiment” (p. Io). 
desire to become one with Margaret through the penetrative potential of sexual union, Olybrius resorts to actions that produce an awareness of the essential frangibility of the body and the inevitability of death. A subtle distinction, of course, is that while death for Margaret represents a transformation into ontological fixity, Olybrius can see no further than the literal, and in the mutilated figure of the saint, he is forced to come face-to-face with the demise of the self and his own eventual transformation into the detritus of the grave.

The transition from phallic desire to corporeal devastation serves partly as a prefiguration of the central and most iconic episode of Margaret's legend, and partly as a distilled refraction (or perhaps reinterpretation) of it. The walls of the cell, which stand in part as a representation of the saint's anatomical integrity, are penetrated by a diabolical dragon that attempts to swallow her, and in this way subsume her essence into its own. The composite violation of anatomical/architectural space can be related to the torture that gives access to the previously unseen workings of Margaret's forbidden interior. Yet the fact that the dragon attempts to swallow her (as opposed, for instance, to burning her with fire) adds an additional level of narrative complexity, presenting both parties in terms of the relationship between contained and containing. The complex symbiotic parallel between Margaret and Olybrius is in this sense all but duplicated, as the identities of saint and monster are also partially conflated. The strength of the parallel is enhanced by a curious quirk in the sanctoral's narration, for despite accepting the canonical account, in which Margaret defends herself with a cross, it proceeds nonetheless to describe a fanciful alternative. In this version, which is marked as apocryphal, the emphasis falls on a more vigorous form of corporeal experience, as the saint is not merely threatened, but swallowed whole. In fact, her ordeal ends only as she makes the sign of the cross, and, in a clear visual parallel of the depiction of her own exposed innards, bursts outwards from the dragon's shattered and mutilated stomach: "se lee que le puso aquel dragón los dientes sobre la cabeça, e la lengua so el calcañar, e la començó a tragar, e ella fizo la señal de la cruz, e rebentó el dragón, e ella escapó" (11. 55-57).

The relationship between Margaret and the dragon establishes a Christo-mimetic parallel that recalls the Crucifixion, the Resurrection, and the shattering of the gates of Hell, and on a deeper typological level, the tale of Jonah and the whale. ${ }^{20}$ It also compels the audience to think again of the prefatory discussion of

${ }^{20}$ Wendy R. Larson argues that Margaret "enacts a type of descensus by being swallowed by the dragon, which may be linked to Christ's descent into hell (often portrayed as the mouth of Leviathan or a dragon)" (2002, p. 26). The parallel is strengthened in the visual tradition by the cruciform 
etymology, and to consider the extent to which the narrative gains in structural unity and coherence through the development of images depicting effusions from within. On a more theoretical level, the episode invites consideration of the subject/object distinction, and the question of how Margaret, while inside the dragon, becomes a part of its liquid interior, just as her own interior is conflated with the outside world through acts of torture and mutilation. This twofold relationship, which blurs the borderline between internal and external, makes it difficult to determine where the frontiers of selfhood begin and end. It can also be related in broader structural terms to the process of scopic sexualization in which Olybrius reformulates Margaret as a body to be penetrated. The common denominator in each instance is that the attempt is unsuccessful, and by asserting the right to corporeal independence, Margaret is able to react with saintly virtue and to triumph in the face of adversity.

The fact that the sanctoral marks the encounter as apocryphal, and therefore unlikely, yet opts nonetheless to retain it, is illustrative of a tension in the legend between the demands of credibility and the aesthetics of spiritual storytelling. It could also potentially be thought of as a half-hearted attempt on the part of a member of the clergy to impede the articulation and circulation of signifiers by imposing a form of ideological manipulation partially at odds with the demands and aesthetic predilections of a popular audience that would have been composed, at least in part, of female believers. It becomes important in this respect to consider its relationship to popular iconographic representations in which the saint is depicted, rather more directly and unapologetically, as bursting outwards from belly of the dragon, often with the hem of her dress still trailing its way belatedly into its mouth. A number of striking examples are attested in the French and Flemish traditions, predominantly in lavishly illustrated books of hours (which would have served as portable guides to individual spiritual development, notably that of women), and in a series of compositions produced in Spain. Of particular note is a panel by Joan Reixach (I4II-86/92), now in the Museu Nacional d'Art de Catalunya (Fig. I), in which the saint emerges serenely from a disturbing, labia-like wound in the dragon's belly whilst holding a long-handled cross tipped at its lower end by a spear point. ${ }^{2 \mathrm{H}}$ Her colourful and

depiction of her torture. A comparably sexualized parallel is with St George, whose phallic sword penetrates the dragon and allows the maiden it sought to devour to lead it away by using her girdle as a leash.

${ }^{21}$ MNAC 200700-000 (tempera and oil with gold leaf). The panel was probably produced in Bocairent, near Valencia, and may have formed part of a retable dedicated to St Michael. 
pristinely unbesmirched garments, which emphasize her spiritual and corporeal desirability, form a stark contrast not only with the blood and gore that ooze outwards from the dragon's mouth and burst entrails, but also with the emphasis of the written account, which makes no reference to the restoration of her garments or the healing of her wounds. It can be compared in this respect to the sobriety of Zurbarán's portrait, now in the National Gallery, London (Fig. 2), in which the saint, depicted in the gaudily multi-coloured trappings of an idealized seventeenth-century shepherdess, stands calmly outside the dragon with a book and a staff in her hands. ${ }^{22}$ Her dignified bearing and flawless virginal beauty are emphasized in part by the hideous appearance of the dragon, which fades into the darkness of the background, and partly by the way in which her gaze reaches directly outwards from the canvas in order to engage the curiosity and spiritual sensitivities of the beholder.

The semiotic fluidity of the dragon episode offers a powerful contribution to the development of Margaret's symbolic identity, for as she emerges from within the boundaries of a composite self, she provides an image of childbirth; not in the sense of a vaginal delivery, but of a caesarean section, a process regarded in the Middle Ages as one that bestowed a special destiny or purpose on those who were "not of woman born" (Blumenfeld-Kosinski). The caesarean is not in this instance an intricate medical procedure, but a form of violent anatomical eruption; so violent, in fact, that it destroys the host, or to adopt a more conceptually loaded term, the mother from whom the issue emerges. It is partly for this reason that Margaret becomes the patron saint of childbirth and parturient women, a function referenced in the concluding portion of the narrative, as she prays specifically for "las que estoviesen en peligro de parto" (1.93). Her notoriety in this respect is reflected by the fact that women in labour would often ask for her passion to be read aloud as a source of inspiration, or to have a copy of it placed on their mouths or wombs, at the very interface between internal and external. For this reason Margaret is frequently depicted, as is the case in Zurbarán's portrait, with a book in her hand. Of perhaps greater significance, however, as Leanne Gilbertson (p. I8I) recognizes, is that new mothers would also sometimes gather up the umbilical cord after a successful delivery in order to offer it to the saint as an ex-voto. They would in this way integrate the most tangible anatomical link between mother and child into the formulation of a complex, composite gynocentric identity.

${ }^{22}$ NGi930 (oil on canvas). For further information, see amongst others Delenda (I, pp. 586588) and Navarrete (pp. II7-II9). 
The representation of the dragon as host/mother plays on a series of universal human neuroses that explore the merger of subject and object in differing ways. At the most basic level of identification, the dragon becomes a representation of biological impossibility, a form of insemination and gestation that shatters our traditional understanding of the borders and limitations of gender and species. Our sense of revulsion could in this respect be compared not simply to images of the corpse and the burrowing worm in literary and pictorial forms such as the dances of death or the body-and-soul debates, but to the realm of science fiction, with films such as Ridley Scott's Alien (1979) exploring the neurosis of male pregnancy and the breached wound in the stomach as a surrogate vagina. ${ }^{23}$ Yet while the legend invites procedures of identification predicated on conceptions of bodily invasion, its most obvious achievement in mimesis is formulated in relation to an implied female audience and a series of neuroses relating to childbirth. In an age of high infant mortality, in which women routinely died or suffered agonizing labour pains, the act of bursting outwards from the belly of the dragon, which in turn reflects on Margaret's own burst entrails, invites an empathetic and deeply compassionate response. The polarity of the image is in this sense inverted, as female members of the audience are invited not simply to identify themselves with pain and suffering, but to experience it, either as a prolepsis, or as an analeptic fusion in which the past of the subject is partially overlaid onto the hagiographic object as the memory of pain becomes a driver in the creation of complex hybrid identity (see Larson, 2003, p. 97). The operation of this process succeeds in drawing the audience more deeply into the conceptual fabric of the narrative, with the rigidity of the extradiegetic self/other borderline collapsing in the face of a powerful emotional challenge to a sense of collective womanhood. Needless to say, this type of identification, as Gilbertson (p. I8I) argues, is most clearly evidenced by artistic representations produced after the Black Death, where Margaret appears younger and her character more vulnerable, almost certainly in recognition of the socio-economic reality of population decline and the increasing pressure on women to produce offspring at an earlier age. The argument could, of course, be taken further, for as the manuscripts of the Gran flos sanctorum are likely to have been copied and circulated during the central and latter portions of the fourteenth century, it may be that the precise shaping of the Castilian version of the legend could be regarded in this respect as a reflection of its intended audience.

${ }^{23}$ For a queer reading of the worm/cadaver relationship in the Dança general de la Muerte, see Beresford (20I4). 
An obvious complication, however, is that, as Ásdís Egilsdóttir (p. 23I) notes, the term dragon was commonly adopted in the Middle Ages as an all-encompassing synonym for large reptiles, including serpents and snakes, notably in the Bible, where draco and serpens are used all but interchangeably. For Egilsdóttir, this semantic uncertainty is a product of folkloric associations relating to questions of regeneration and rebirth, particularly in the cults of pagan goddesses and their syncretistic absorption into Christianity. The Virgin Mary, for instance, is occasionally presented in folklore as a protective mother and paragon of fertility who stands over a serpent or dragon. She is characterized in this way, Egilsdóttir argues, "as both Ecclesia and a second Eve predestined to bring about the redemption of humanity" (p. 32I). The question of regeneration, on the other hand, can be related not only to the image of rebirth suggested by the shedding of the snake's skin, but to the lunar and menstrual cycles, which traditionally evoke impressions of fertility and mystical womanhood. The underlying connotations of the relationship are spelled out perhaps most clearly in the text of Revelation I2, where a seven-headed dragon threatens a woman who is about to give birth. The specificity of her depiction, "with the moon under her feet and a crown of twelve stars", has commonly been identified as a source for the iconography of the Immaculate Conception. ${ }^{24}$

A sense of the power of mystical womanhood is perhaps most clearly emphasized, however, by the second and climactic prison episode, where the saint is confronted by an anthropomorphic devil. Felling him to the ground by tugging at his hair, an aspect of the anatomy characterized by a range of potent symbolic signifiers, Margaret confidently promotes an image of female supremacy: “Sienpre deve estar el diablo so los pies de la muger!" (1l. 62-63). The inversion of traditional gender paradigms can be related partly to the image of pregnancy and the triumph over Olybrius, but also, as Egilsdóttir (p. 23I) affirms, to the iconography of the Virgin. There is also, perhaps, a passing resemblance to St Juliana, who clasps the devil in chains before throwing him into a privy. ${ }^{25}$ The devil, conscious of his humiliation at the hands of a fifteen-year old girl, gives voice to an admission of shame predicated on a dialectical opposition between the sexes.

${ }^{24}$ For the cult of the Virgin, see Twomey. Support for Egilsdóttir's reading is offered by the Bestiary tradition, where the young of the female viper burst out violently through her stomach. As Alan Deyermond recognizes, this image appears both in Celestina and the poetry of Florencia Pinar, where love is presented as an eviscerating force. See also McFadden (pp. 482-483) and BlumenfeldKosinski (p. Ion4).

${ }^{25}$ For Juliana, see BNM I2688 fols. $280^{\text {va }}-28 \mathrm{I}^{\text {vb }}$ and Escorial h-III-22 fols. $177^{\text {va }}-179^{\text {ra }}$. 
The episode is perhaps most important, however, in terms of its manipulation of traditional symbolism, for while hair commonly functions as a signifier of male prowess, with acts of tugging or removing connoting forms of humiliation and/ or emasculation, the foot often stands (notably as a result of the foot/shoe metaphor and the implied relationship between contained and containing) as a proxy for the sexual organ. The saint's triumph is not solely in this sense an inversion of traditional gender polarities, but a process of sexually ritualized emasculation that can be related to a range of literary and folkloric precedents.

The overall structure of the narrative is in this sense deeply ironic: the fair maiden that Olybrius once desired to possess rejects the phallus as an instrument of domination and is subjected as a result to a series of equivalent forms of corporeal transgression, with the inner harmony of the body violated by a range of phallic surrogates. Swallowed by the dragon, Margaret is presented for a second time as an article for consumption, but having reasserted her symbolic identity by refusing to be contained and making the sign of the cross, she explodes outwards from its belly. The humiliation of the anthropomorphic devil brings the tripartite sequence to a close, as he enters the prison in order to deceive her, but is physically overwhelmed. She thereafter subjects him to a powerful verbal tirade, which shifts the emphasis of the narrative from the violence inflicted on the somatic exterior to the emergence of the inner word (see Dendle, pp. 48-49). The episode in this way formulates an arresting paradox: the once idealized shepherdess is presented no longer as a passive victim or sexualized object, but like Olybrius, as the active instrument of coercive domination and sexualized torture and violence. The result is a process of inversion, with the fragility of the self/other distinction challenged by a process of polymorphous cross-identification capable of obscuring the dialectical clarity of the relationship between torturer and victim.

Our final impression of Margaret is one of exceptionality, and it is striking that just as the prefatory discussion of etymology played on the relationship between container and contained, discussing effusions of blood from within, the concluding portion of the narrative is dominated by a series of additional references to spatial dynamics. The devil's humiliating confession, for instance, first alludes to human bodies as the containers from which he is expelled, before he compares his situation to that of Solomon, who trapped devils in a glass only for them to escape as a result of an act of deceit. Margaret, likewise, is released from prison before being stripped of her garments and burned with flaming torches until her flesh melts away and her bones become exposed. This threefold progression, which seeks to remove or destroy the elements within which the essence of her selfhood is contained, comes to an end only when she is re-contained within 
a tub of water. Yet even this, far from augmenting her pain, is conceptually redefined, as is the case with the earlier tortures, as a signifier of baptism. The fact that it shatters as the result of a miraculous earthquake (an eruption from deep within the earth's interior), can be related not only to the mutilated bellies of saint and dragon, but to the preface, and possibly also, as Gilbertson (p. 186) suggests, to the basins used by midwives. It can also perhaps be related to the fate of the five thousand pagan onlookers, who progress from abject empathy to sympathetic conversion, and are themselves decapitated by Olybrius's henchmen.

For Fromer, the decapitation of the five thousand is an event that can be appraised in relation to Foucauldian theory, as the spectacle of torture and death produces a sense not of Olybrius's judicial power, but of the potential for rejection and revolt. The converts, who become witnesses to his weakness and ineffectuality, engage in a process of recognition and disavowal that leads them to affix their attentions on an ineffable sovereign whose authority is rendered visible through the body of Margaret. The corporeality of her experience, which continues to be conditioned and mediated by their gaze, leads in this way to a situation in which, rather than being sexualized, she becomes a catalysing focal point for evolutionary developments in self-identity. The fundamental implication is one that impacts most pertinently on questions of temptation, for as Fromer affirms: "Margaret's battle with the corporeal is not located within herself, but externally, in the outer world of the physical and the visible, thus transforming private struggles into public ones and allowing the community to witness the power of God through Margaret" (p. Ioo). It is perhaps inevitable in this respect that Olybrius, now defeated and demoralized, has little option but to destroy that which he once desired. The paradox is obvious: rather than affirming the extent of his power, he succeeds in cementing the position of the saint's body as a locus of realization in which the invisible and supernatural power of the divine is rendered publicly perceptible.

Margaret comes in this way to the end of her earthly travail, but as the narrative has carefully emphasized, death is not an act of cessation but a transitional obstacle to be negotiated on the path to celestial fixity. She has been imprisoned, racked, whipped with rods, lacerated, burned, swallowed by a dragon, and confronted by a devil, but has in each instance relied on the profound interiority of her faith, which remains unaffected by attacks directed against her disposably ephemeral exterior. ${ }^{26}$ As an audience, we identify strongly with her suffering,

${ }^{26}$ It is by no means coincidental in this respect that she is described specifically as being "llena de temor de Dios" (1. IOI). 
and whilst we appreciate that the process of corporeal destruction is a necessary prerequisite for recognition as a martyr, we instinctively subject ourselves to a process of mimetic identification and experience her pain as if it were in some ways our own. The result is a paradoxical situation in which suffering is presented not merely as a positive, but as one that becomes functionally integral to the formulation of intersubjective bonds and the establishment of an ontologically stable Christian identity, whether it be individual or collective. In fact, without pain, the wheat cannot be separated from the chaff, or the soul from the body; nor can the narrative iterate a culturally conditioned and theologically acceptable response for believers to emulate and in this way reaffirm the boundaries of selfhood. ${ }^{27}$

Margaret's suffering also emphasizes the power of the Church, for despite functioning as an individual, she remains a stand-in for the collective body politic, and as she is threatened and attacked but emerges triumphant, she becomes a symbol of impassible Christian resilience. ${ }^{28}$ Her significance could potentially be related in this respect to the allegorical figure of Ecclesia, who is traditionally depicted in iconography as a beautiful young woman replete with a crown and holding a chalice and/or long-handled cross. Crucial to note in this respect is that while Margaret is appraised in the prefatory discussion in terms of the effusion of blood from within, the chief iconographic attribute of Ecclesia is the blood that she gathers as she emerges from the wound in Christ's side (see Spreadbury, pp. 95-96). The strength of the parallel is enhanced partly by a reference to the "corona loable" (11. 97-98) which Margaret receives as a reward for her sacrifice, but perhaps most conspicuously by the way in which she is at times depicted (notably in Reixach's late fifteenth-century panel) as emerging from the belly of the dragon with a long-handled cross in her hand. ${ }^{29}$ The common denominator, of course, is an emphasis on the miraculous nature of (re)birth and mystical motherhood. It also, albeit on a deeper typological level, recalls the birth of Eve from Adam's rib and the formulation of a complex, ontologically interdependent identity. It is in this sense that Margaret's legend can be related to a rich seam

${ }_{27}^{27}$ For pain and the late medieval tendency towards philopasionism, see Cohen.

${ }^{28}$ As Mills writes: "Insofar as the martyr and the Church are analogous to one another with regard to insentience and corporeal wholeness, they possess parallel qualities of insuperability; to the extent that both are represented undergoing ordeals that open them up to the threat of extreme violence, they are each connected, by a process of imaginative displacement, with the 'realness' of pain" (p. I20).

${ }^{29}$ A further correspondence is the pairing of Ecclesia and Synagoga, with the blindness of the latter recalling Olybrius's ignorance. See also Spreadbury (pp. 97-98). 
of deeper typological associations that are not solely somatic or body-centric in nature, but grounded in an appreciation of the fact that corporeal destruction is an invaluable transformative experience capable both of defining and defending the borders of selfhood, and of assimilating the individual into a broader process of spiritual identification. Indeed, as Margaret strives throughout her legend to become Christ-like, emulating the suffering of the Saviour with saintly impassivity, we are invited in turn to become Margaret-like, and engage in a process of mimetic identification in which we become active participants in the destruction of her corporeal essence. We are able in this way not merely to transcend the torture and pain of everyday life, but to use her example as a way of avoiding the far greater horrors of eternal damnation. 


\section{APPENDIX}

\section{LA YSTORIA DE SANTA MARGARITA}

[BNM 780 fol. $\left.245^{\text {ra }}\right]$ Aquí comiença la ystoria de Santa Margarita

"[M]argarita" es dicha de una piedra preciosa que es llamada en latín "Margarita", e es llamada en nuestra lengua [fol. 245 ${ }^{\text {rb }}$ " "aljófar", e es piedra blanca e pequeña e virtuosa. E asý Santa Margarita fue blanca por la virginidat, e pequeña por la humilat, e virtuosa por las obras maravillosas. E dízese que aquesta piedra preciosa (conviene saber, el aljófar), aprovecha mucho al soltamiento de la sangre e a la pasión del coraçón e al esfuerço del spíritu. E asý Santa Margarita ovo virtud en el derramiento de la su sangre por fortaleza, ca sufrió el martirio varonilmente, e ovo virtud contra la pasión del coraçón (conviene saber, contra el diablo), ca lo venció e sobró, e esforçó el spíritu de muchos, e convirtiólos a la creencia santa por la su enseñança. E la su ystoria escrivió Theótimo, ${ }^{2}$ que fue varón muy sabio.

E Santa Margarita fue de la cibdat de Anthiochía, e fija de un patriarcha de los gentiles que avía nonbre Teodosio, e fue dada a criar a una ama, e fue baptizada de que llegó a hedat de discreción, e aborrescióla mucho el padre por esta [fol. $245^{\text {va }}$ ] razón. E como llegase a los quinze ańos, e guardase con otras moças las ovejas de la ama que la criara, pasó por allí un adelantado que avía nonbre Olibrio, e veyéndola ser moça fermosa, fue encendido en $e l$ su amor, e mandó a alg $u$ nos de sus servidores que con $e$ l yvan que la tomasen e $e^{4}$ gela levasen, e sy fuese libre que casaría con ella, e sy fuese sierva que la tomaría por manceba.

E como ge la traxesen delante, e le preguntase de su linaje, e sy era gentil o judía o christiana, respondióle ella e dixo: "El mi linaje es noble, e a mí llaman Margarita, e só christiana." E díxole el adelantado: "Las dos cosas primeras conviene a ti bien (conviene saber, la nobleza del linaje e el nonbre), porque eres fermosa asaz, mas lo tercero non conviene a ty porque moça tan fermosa e tan noble non deve aver por dios al crucificado." E respondióle Santa Margarita e dixo: “¿De dónde sabes tú que mi Señor "Jhesu Christo fue crucificado?" E respondióle el [fol. $245^{\mathrm{vb}}$ ] adelantado e dixo: "De los ${ }^{6}$ libros de los christianos sé yo que el su Christo fue crucificado." E díxole Santa Margarita: "Como en los libros de los christianos se lea la pena del Señor ${ }^{7}$ Jhesu Christo e la su gloria, grand vergüeña es a vós creer lo uno e negar lo

\footnotetext{
${ }^{I}$ la: la su (crossed through).

2 Theótimo: timo (crossed through); filo (added in margin).

3 sus: los (crossed through); sus (added in margin).

${ }^{4}$ e (added in supra).

5 mi Señor (added in margin).

${ }^{6}$ los: los los (crossed through).

${ }^{7}$ Señor (added in margin)
} 
30 otro." $^{\prime 2}$ E como Santa Margarita dixese que avía seýdo crucificado por la nuestra redención, e bivía agora para sienpre, fue muy yrado el adelantado, e mandóla encarcelar.

E otro día mandóla traher delante de sý, e díxole: "Moça liviana, ave merced de tu fermosura, e adora los nuestros dioses por que te pueda yr bien." E respondióle Santa Margarita e dixo: "Yo adoro a aquél que temen la tierra e el mar e los vientos e todas las cosas." E díxole el adelantado: "Si non fizieres lo que te digo, faré despedaçar el tu cuerpo." E díxole Santa Margarita: "Jhesu Christo, mi Señor, "s se dio por mí a muerte, e por ende non he yo temor de morir por el su amor."

E oyendo esto el adelantado, [fol. $246^{\text {ra }}$ ] mandóla colgar en un tormento que era llamado eculeo, e açotar con vergas con mucha crueldat, e rasgar sus carnes con peynes de fierro, fasta que se le parescían los huesos. E corría la sangre de su cuerpo asý como de una fuente muy clara, e lloravan todos los que allí estavan, e dizían: "Margarita, grand conpasión avemos de ti, porque veemos despedaçar el tu cuerpo con tan grand crueldat, e que pierdes la tu fermosura por la tu descrencia e porfía, e sy ál non, faz agora lo que te dize el adelantado por que puedas aver vida." E ella, oyendo aquesto, respondióles e dixo: "Partídvos de mí, malos consejeros, e ydvos, que aqueste tormento del mi cuerpo es salvación del mi coraçón.” E dixo al adelantado: "Can desvergonçado e león ravioso, en mi cuerpo puedes aver poderío, mas mi Señor "Jhesu Christo guardará la mi alma, que non ayas poderío en ella.” E el adelantado cubría su cara con $e$ manto, non pudiendo ver tanta sangre como salía della, e fízola quitar del eculeo ${ }^{\mathrm{I} 2}$ e en|cerrar [fol. $246^{\mathrm{rb}}$ ] en la cárcel.

E descendió a ella en la cárcel grand claridat, e ella oró al Señor que le demostrase veýblemente al diablo que peleava contra ella. E aparescióle luego un dragón muy grande, e arremetióse a ella para la tragar, e ella fizo la señal de la cruz, e desapareció luego el dragón. E aun en una ystoria se lee que le puso aquel dragón los dientes sobre la cabeça, e la lengua so el calcańar, e la començó a tragar, e ella fizo la señal de la cruz, e rebentó el dragón, e ella escapó. Aquesto enpero que es dicho que la tragava el dragón e rebentó es creýdo ser apócrifo. ${ }^{\text {I3 }}$

E el diablo mudóse en semejança de omne por la engañar, e veyéndolo Santa Margarita, derribóse a orar. E desque se levantó de la oración, llegóse a ella el diablo, e tomóla por la mano, e díxole: “¡Abástete lo que has fecho! ¡Cesa ya de me perseguir!" E ella tomólo por los cabellos, e derribólo a tierra, e dixo: “¡Sienpre deve estar el diablo so los pies de la muger!" [fol. $246^{\mathrm{va}}$ ] E el diablo dava bozes e dizía: "Margarita bienaventurada, vencido me has, e sy me venciera algunt omne mancebo, non

8 otro (added in supra).

${ }^{9}$ cosas: cosas dadas (crossed through).

Io $\mathrm{mi}$ Señor (added in margin).

${ }^{\text {II }} \mathrm{mi}$ Señor (added in margin).

${ }^{12}$ eculeo: ecuelo.

${ }^{13}$ E aun ... apócrifo (struck through). 
65 lo toviera a desonrra e vergüeńa, mas he grand dolor porque me veo vencido de una donzella tierna, quanto más que tu padre e tu madre ovieron comigo mucha amistad." E ella, oyendo aquesto, apremió lo que le dixiese a qué viniera, e él respondióle e dixo que la viniera a consejar que siguiese el consejo que le dava el adelantado.

E preguntóle ella por qué perseguía e tentava a los christianos por tantas maneras, e respondióle él e dixo que naturalmente aborrescía a los omnes virtuosos, e que aunque era desechado dellos muchas vezes, sienpre enpero se trabajava por los engañar, porque avía enbidia de la bienandança que se esforçava a alcançar, e que aunque él non la podía cobrar, deseava enpero de la quitar a los que trabajavan por la alcançar. E aun dezía que Salomón avía encerrado grand muchedunbre de diablos en un vaso, e que [fol. $246^{\mathrm{vb}}$ ] después de la muerte de Salomón, lançavan los diablos fuego de aquel vaso, e los omnes que veýan aquesto pensavan que estava en aquel vaso algu $n$ t grand thesoro, e quebrantáronlo, e salieron los diablos que estavan en $e ́ 1$ encerrados. E desque el diablo ovo dicho aquestas cosas, dexólo $\mathrm{yr}^{\mathrm{r}}{ }^{4}$ Santa Margarita e díxole: "Da a fuyr, mesquino." E desaparesció luego aquel spíritu malino. E ella quedó segura, creyendo que pues que venciera al diablo, vencería a su servidor el adelantado.

E otro día ayuntóse el pueblo, e fue traýda Santa Margarita delante el adelantado, e non queriendo sacrificar, fue desnudada, e fue quemado todo el su cuerpo con fachas ardiendo fasta los huesos, en manera que todos se maravillavan como moça

85 tan tierna podía sofrir tan grandes penas. E después de aquesto, mandóla atar el adelantado, e meter en una pila llena de agua por que el mudamiento de las penas se le acrescentasen los dolores, mas tremió adesora la tierra, e salió Santa Margarita sana [fol. $247^{\text {ra }}$ ] del agua, e creyeron entonces cinco ${ }^{\text {Is }}$ mill omnes, e fuero $n$ descabeçados por el amor del Señor. E temiendo el adelantado que se convirtirían muchos sy la detoviese más, mandóla luego degollar.

E ella demandó espacio para orar, e oró por sý e por los sus perseguidores, e por los que fiziesen memoria de la su muerte, e por los que la llamasen en su ayuda devotamente, e por las que estoviesen en peligro de parto. E vino luego a ella una boz del cielo, e díxole que eran oýdas las sus peticiones, e serían acorridos los que demandasen la ayuda de las sus oraciones. E ella levantóse luego de la oración, e dixo al que la avía a descabeçar que tomase su espada e la firiese quando quisiese. $\mathrm{E}$ él tomó su espada e cortóle la cabeça de un golpe. E ella pasó al Señor por corona loable de martirio a veynte días de julio, comoquier que en otro lugar se lee que fue martiriada a cinco días de julio.

Ioo E de aquesta santa virgen dize Sant Anbrosio: ${ }^{16}$ San|ta [fol. $\left.247^{\text {rb }}\right]$ Margarita fue llena de temor de Dios, e conpuesta de toda religión, e abondada de conpunción, e

${ }^{14}$ lo yr: lo (struck through); lo yr (added in margin).

Is cinco: 1 cinco (struck through).

${ }^{16}$ Sant Anbrosio: un santo varón (struck through); Sant Anbrosio (added in margin). 
loable por honestad, e de paciencia syngular, e non era en ella cosa alguna contraria a la religión christiana. E era aborrescida de su padre, e amada del rey perdurable.

Aquí acaba la ystoria de la bienaventurada Santa Margarita, a honrra e gloria ios del Nuestro Señor Jhesu Christo, el qual bive con el Padre e con el Spíritu Santo, e reyna por todos los siglos. AmÉn. 
CITED WORKS

Anzieu, Didier, 1989: The Skin Ego (trans. C. Turner), New Haven, CT. Baños Vallejo, Fernando, and Isabel Uría Maqua (eds.), 2000: La leyenda de los santos: 'flos sanctorum' del ms. 8 de la Biblioteca Menéndez Pelayo, Estudios de Literatura y Pensamiento Hispánicos I8, Santander.

Benthien, Claudia, 2002: Skin: On the Cultural Border Between Self and the World (trans. T. Dunlap), European Perspectives, New York.

Beresford, Andrew M., 2010: The Severed Breast: The Legends of Saints Agatha and Lucy in Medieval Castilian Literature, Newark, DE.

— 20I4: "Abjection, Marriage, and the Burrowing Worm: The Body as Bounded System in the Dança general de la Muerte", Bulletin of Hispanic Studies, 91, pp. 965-980.

Binski, Paul, 1996: Medieval Death: Ritual and Representation, London.

Blumenfeld-Kosinski, Renate, 1990: Not of Woman Born: Representation of Caesarean Birth in Medieval and Renaissance Culture, Ithaca, NY.

Butler, Judith, 1987: Subjects of Desire: Hegelian Reflections in Twentieth-Century France, New York.

Camille, Michael, 1998: "Mimetic Identification and Passion Devotion in the Later Middle Ages: A Double-Sided Panel by Meister Francke", The Broken Body: Passion Devotion in Late-Medieval Culture (eds. A. A. MacDonald, H. N. B. Ridderbos, and R. M. Schlusemann), Mediaevalia Groningana 2I, Groningen, pp. 183-210.

Chaudhuri, Shohini, 2006: "The Male Gaze", Feminist Film Theorists: Laura Mulvey, Kaja Silverman, Teresa de Laurentis, Barbara Creed, Routledge Critical Thinkers, London, pp. 3I-44.

Cohen, Esther, 1995: "Towards a History of European Sensibility: Pain in the Later Middle Ages", Science in Context, 8.I, pp. 47-74.

Connor, Steven, 2004: The Book of Skin, Ithaca, NY.

Delenda, Odile, 2009: Francisco de Zurbarán, I598-1664, 2 vols., Madrid.

Dendle, Peter, 2003: "Pain and Saint-Making in Andreas, Bede, and the Old English Lives of St. Margaret", Varieties of Devotion in the Middle Ages and Renaissance (ed. S. C. Karant-Nunn), Arizona Studies in the Middle Ages and the Renaissance 7, Turnhout, pp. 19-52.

Deyermond, Alan, 1978: "The Worm and the Partridge: Reflections on the Poetry of Florencia Pinar”, Mester, 7.I-2, pp. 3-8.

Dresvina, Juliana, 2007: "The Cult of St Margaret of Antioch in Medieval England”, $\mathrm{PhD}$ Thesis, Cambridge University. 
Easton, Martha, 2002: "Pain, Torture and Death in the Huntington Library Legenda aurea", Gender and Holiness: Men, Women and Saints in Late Medieval Europe (eds. S. J. E. Riches and S. Salih), Routledge Studies in Medieval Religion and Culture I, London, pp. 49-64.

Egilsdóttir, Ásdís, 2002: "St Margaret, Patroness of Childbirth", Mythological Women: Studies in Memory of Lotte Motz (1922-1997) (eds. R. Simek and W. Heizmann), Studia Medievalia Septentrionalia 7, Vienna, pp. 319-330.

Foucault, Michel, 1977: Discipline and Punish: The Birth of the Prison (trans. A Sheridan), New York.

Fromer, Julie E., 2005: "Spectators of Martyrdom: Corporeality and Sexuality in the Liflade ant te Passiun of Seinte Margarete", Intersections of Sexuality and the Divine in Medieval Culture: The Word Made Flesh (ed. S. M. Chewning), Aldershot, pp. 89-106.

Gaunt, Simon, 1995: Gender and Genre in Medieval French Literature, Cambridge Studies in French 53, Cambridge.

Gilbertson, Leanne, 2002: "The Vanni Altarpiece and the Relic Cult of Saint Margaret: Considering a Female Audience”, Decorations for the Holy Dead: Visual Embellishments on Tombs and Shrines of Saints (eds. S. Lamia and E. Valdez del Álamo), International Medieval Research 8: Art History Subseries I, Turnhout, pp. 179-190.

Gravdal, Kathryn, 1991: Ravishing Maidens: Writing Rape in Medieval French Literature and Law, Philadelphia.

Grosz, Elizabeth, 1989: Sexual Subversions: Three French Feminists, Sydney.

- 1990: "The Body of Signification", Abjection, Melancholia, and Love: The Work of Julia Kristeva (eds. J. Fletcher and A. Benjamin), Warwick Studies in Philosophy and Literature, London, pp. 80-I03.

Hill, Carole, 2005: “Leave my virginity alone': The Cult of St Margaret of Antioch in Norwich: In Pursuit of Pragmatic Piety", Medieval East Anglia (ed. C. Harper-Bill), Woodbridge, pp. 225-245.

Kristeva, Julia, 1982: Powers of Horror: An Essay on Abjection (trans. L. S. Roudiez), New York.

—, 2012: The Severed Head: Capital Visions (trans. J. Gladding), European Perspectives, New York.

Larson, Wendy R., 2002: "The Role of Patronage and Audience in the Cults of Sts Margaret and Marina of Antioch", Gender and Holiness: Men, Women and Saints in Late Medieval Europe (eds. S. J. E Riches and S. Salih), Routledge Studies in Medieval Religion and Culture I, London, pp. 2I35 . 
_ 2003: "Who is the Master of This Narrative? Maternal Patronage of the Cult of St. Margaret", Gendering the Master Narrative: Women and Power in the Middle Ages (eds. M. C. Erler and M. Kowaleski), Ithaca, NY, pp. 94-IO4.

Lechte, John, I990: "Horror, Love, Melancholy", Julia Kristeva, Critics of the Twentieth Century, London, pp. I57-198.

Lewis, Katherine J., 2000: “Lete me suffre': Reading the Torture of St Margaret of Antioch in Late Medieval England", Medieval Women: Texts and Contexts in Late Medieval Britain. Essays for Felicity Riddy (eds. J. Wogan-Browne, R. Voaden, A. Diamond, A. Hutchison, C. M. Meale, and L. Johnson), Medieval Women: Texts and Contexts 3, Turnhout, pp. 69-82.

McAfee, Noëlle, 2004: "Abjection", Julia Kristeva, Routledge Critical Thinkers, London, pp. 45-57.

McFaden, Brian, 2005: “The Books of Life': Theotimus as Narrator of Identity in the Old English Lives of St. Margaret”, English Studies, 86, pp. 473-492.

Merback, Mitchell B., 1999: The Thief, the Cross and the Wheel: Pain and the Spectacle of Punishment in Medieval and Renaissance Europe, London.

Miller, William I., 1997: The Anatomy of Disgust, Cambridge, MASS.

Mills, Robert, 2005: Suspended Animation: Pain, Pleasure and Punishment in Medieval Culture, London.

Mulvey, Laura, 1975: "Visual Pleasure and Narrative Cinema", Screen, I6.3, pp. 6-I8.

- 1989: Visual and Other Pleasures, Basingstoke.

Murray, Jacqueline, 2002: “The law of sin that is in my members': The Problem of Male Embodiment", Gender and Holiness: Men, Women and Saints in Late Medieval Europe (eds. S. J. E. Riches and S. Salih), Routledge Studies in Medieval Religion and Culture I, London, pp. 9-22.

Navarrete Prieto, Benito, 2013: Santas de Zurbarán: devoción y persuasión, Seville.

Oliver, Kelly, 1993: “The Abject Mother", Reading Kristeva: Unraveling the Double-Bind, Bloomington, pp. 48-68.

Robertson, Elizabeth, 1991: "The Corporeality of Female Sanctity in The Life of Saint Margaret", Images of Sainthood in Medieval Europe (eds. R. BlumenfeldKosinski and T. Szell), Ithaca, NY, pp. 268-287.

Scarry, Elaine, 1985: The Body in Pain: The Making and Unmaking of the World, Oxford.

Smith, Anne-Marie, 1998: "The Abject, the Maternal and Melancholy", Julia Kristeva: Speaking the Unspeakable, Modern European Thinkers, London, pp. $30-48$. 
Spreadbury, Jo, 1998: "The Gender of the Church: The Female Image of Ecclesia in the Middle Ages", Gender in Christian Religion: Papers Read at the 1996 Summer Meeting and the 1997 Winter Meeting of the Ecclesiastical History Society (ed. R. N. Swanson), Studies in Church History 34, Woodbridge, pp. 93-IO3.

Treharne, Elaine M., 1990: “'They should not worship devils ... which neither can see, nor hear, nor walk': The Sensibility of the Virtuous and The Life of St. Margaret", Proceedings of the Patristic, Medieval, and Renaissance Conference, I5, pp. 22I-236.

Twomey, Lesley K., 2008: The Serpent and the Rose: The Immaculate Conception and Hispanic Poetry in the Late Medieval Period, Studies in Medieval and Reformation Traditions 132, Leiden.

Walter, Katie L., ed., 2013: Reading Skin in Medieval Literature and Culture, The New Middle Ages, London.

Winstead, Karen A., 1997: Virgin Martyrs: Legends of Sainthood in Medieval England, Ithaca, NY.

Withycombe, Susan Mary W., 1992: "Seinte Margarete: A Late Old English Perception of Feminine Sanctity”, Parergon, new series, I0.2, pp. I67-I79. 


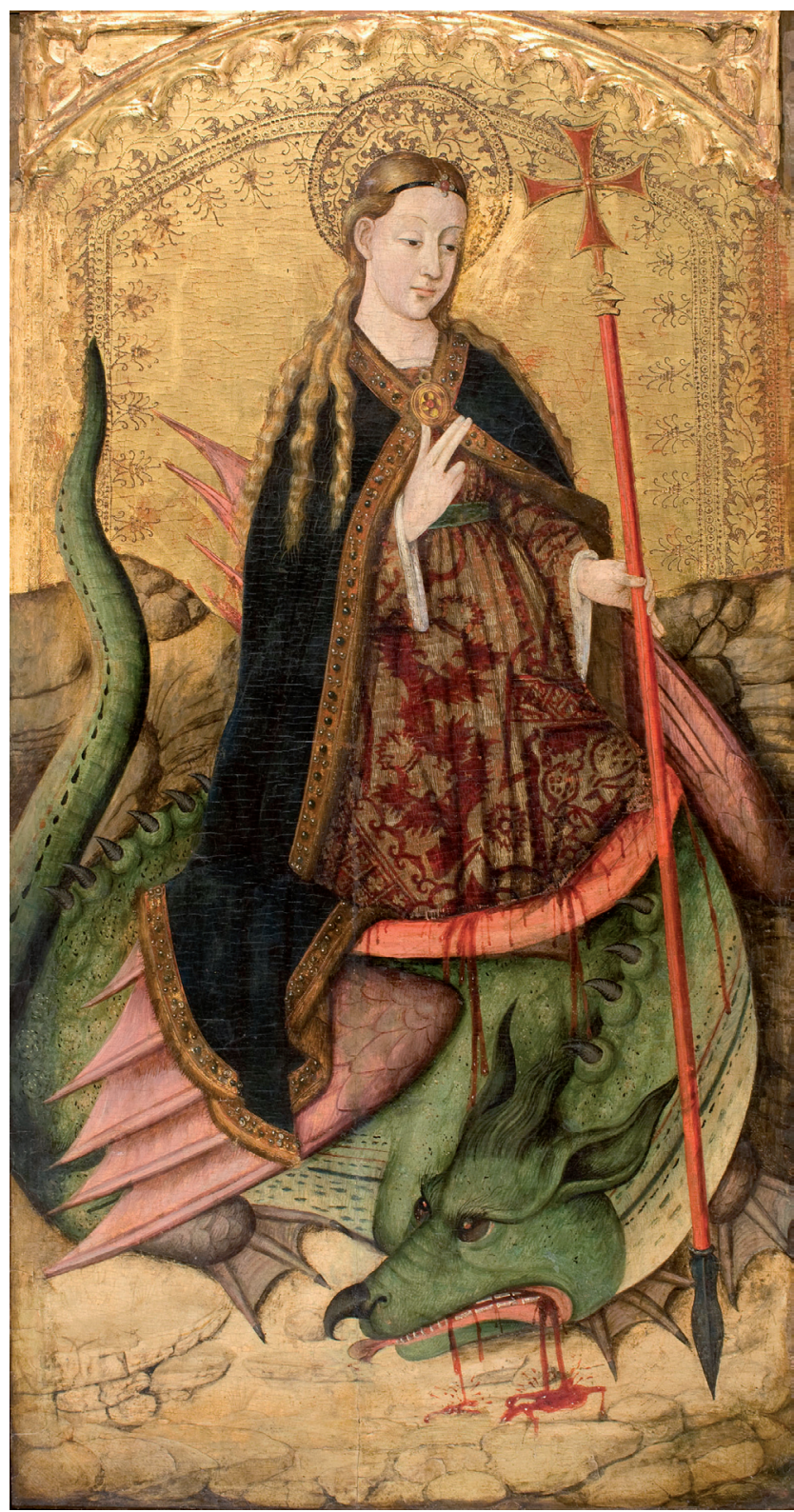

Fig I. Joan Reixach, Saint Margaret, late fifteenth century. Barcelona, Museu Nacional d'Art de Catalunya. 


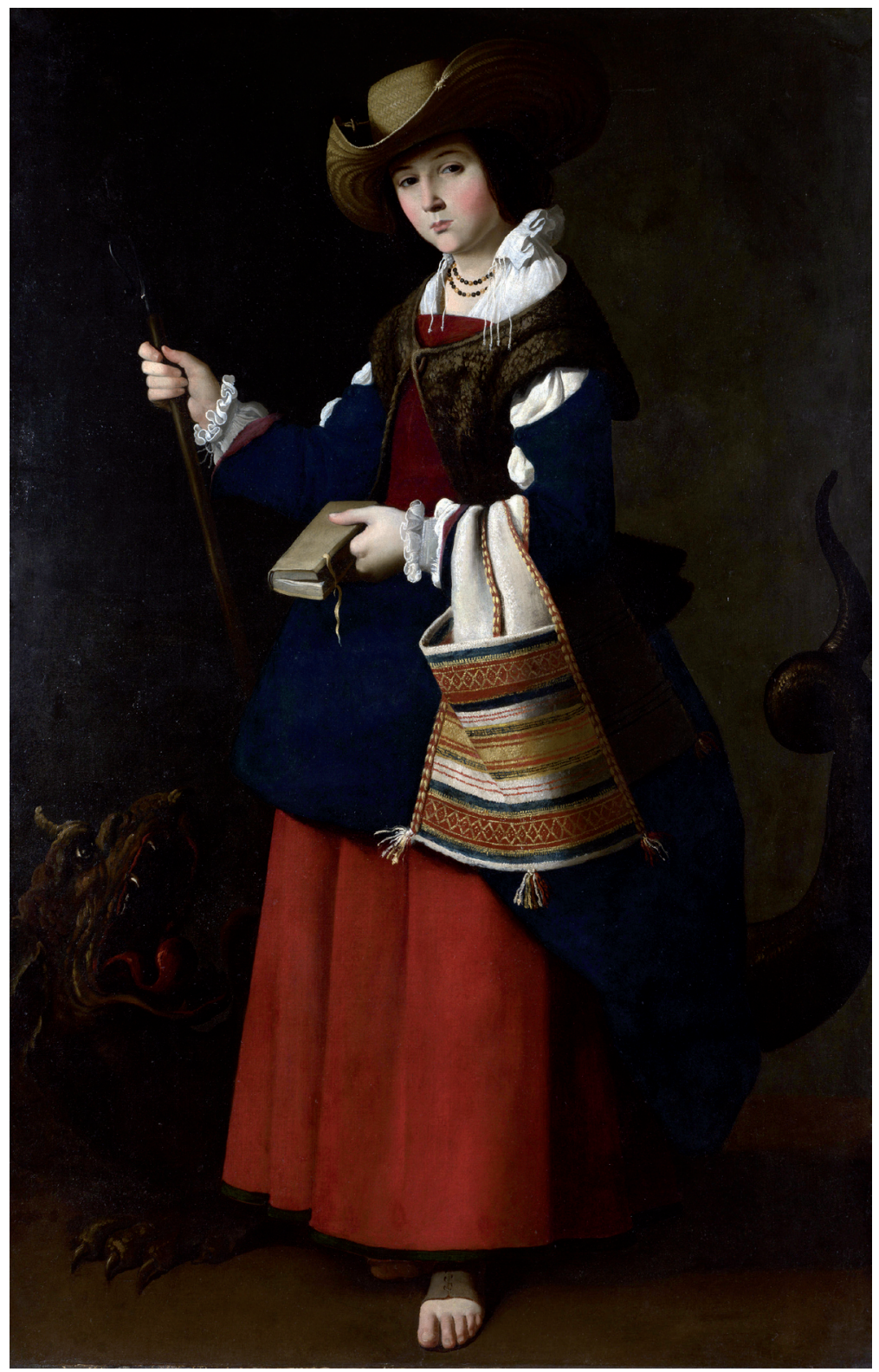

Fig 2. Francisco de Zurbarán, Saint Margaret, ca. I645-50. London, National Gallery. 